\title{
(9)
}

\section{Demographic Factors and Herding Behaviour of Investors: Moderating Role of Islamic Religiosity}

\author{
Saeed Ahmad Sabir ${ }^{a}$, Tasawar Javed ${ }^{b}$, Waseem Ul Hameed ${ }^{c}$, Hummaira Qudsia Yousaf ${ }^{d}$ \\ ${ }^{a}$ PhD Scholar, School of Economics, Finance and Banking, Universiti Utara Malaysia \\ Email: sasabir422@gmail.com.pk \\ ${ }^{\mathrm{b}}$ Assistant Professor, Department of Management Sciences, The Islmia University of Bahawalpur, Pakistan \\ Email: tasawar.javed@iub.edu.pk \\ ${ }^{\mathrm{c}}$ School of Economics, Finance and Banking, Universiti Utara Malaysia \\ Email: expert_waseem@yahoo.com \\ ${ }^{\mathrm{d}}$ Assistant Professor, Department of Management Sciences, Superior University Lahore, Pakistan \\ Email: humaira.yousaf@superior.edu.pk
}

\begin{tabular}{l}
\hline ARTICLE DETAILS \\
\hline History: \\
Accepted 21 Aug 2020 \\
Available Online 30 Sep 2020 \\
\hline Keywords: \\
Herding behaviour, Islamic \\
religiosity, Demographic factors, \\
Pakistan stock exchange (PSX)
\end{tabular}

JEL Classification:

G4O,G41, G1O

DOI: $10.47067 /$ ramss.v3i2,53

\begin{abstract}
Investors indulge in biases while making investment decision because investment decision making in stock market is a difficult process. One of the factors that affect risk taking behaviour of individual investors is Demographic factor. However, little work has been done to investigate the effect of demographic factors on herding behaviour of individual investors of Pakistan stock exchange. Therefore, the ultimate aim of this study is to highlight the role of the effect of demographic factors on herding behavior of investors with moderating role of Islamic religiosity. Quantitative research method was employed and data collected was collected from 166 individual investors by using survey questionnaires. Convenience sampling method was used to collect the data. Partial Least Squares analysis was conducted to test the hypotheses. The findings of this study directed that Islamic religiosity moderate the relationship of demographic factors with herding behaviour. This study is contributed a new empirical insights on behaviour of Pakistan stock market's investors, therefore the results of this study have implications for policy makers of Pakistan stock exchange (PSX) while they making the strategies related to investment.
\end{abstract}

(C) 2020 The authors. Published by SPCRD Global Publishing. This is an open access article under the Creative Commons Attribution-

NonCommercial 4.0

Corresponding author's email address: sasabir422@gmail.com.pk

\section{Introduction}

Demographic factors have significant effect on the behaviour of stock market investors (Kumar \& Goyal, 2016). Evidence from the literature shows that impact of demographic factors not only limited 
to risk taking behaviour of individual investors (Spyrou, 2013), but it also affect the investment decision (Hoffmann, Post, \& Pennings, 2013). Investors make investment decision in uncertain and risky situation. Investment decisions specifically in stock market, are difficult processes as these represent the selection of stocks among various alternatives considering the information gathered and analysed by the investor (Pak \& Mahmood, 2015; Sabir, Mohammad, \& Shahar, 2018). Moreover, situations of uncertainty is a common characteristic of contemporary stock markets and investment decisions making particularly in this situation is a most crucial challenge for investors (Kumar \& Goyal, 2016). Therefore, Investment decision-making can be defined as a complicated multi-step process of choosing a particular alternative from many available alternatives and this process is influenced by various personal, technical and situational factors. Risk tolerance attitudes of investors may differ from each other (Bosner \& Lakehal-Ayat, 2008) because investment decisions are often made in different risky environments (Nga \& Ken Yien, 2013). Risk taking attitudes may depend upon different demographical factors like age, gender, family background, income and occupation (Nga \& Ken Yien, 2013).

Theories of traditional finance like efficient market hypothesis invented that information regarding alternative investment opportunities is equally available to all investors and these investors illuminate the information in a rational manner. While, behavioural finance theory i.e prospect theory of Tversky and Kahneman (1973) argued that investors make wrong investment decisions due to lack of understanding of financial behaviour. Tversky and Kahneman (1973), established prospect theory and described that the investment decisions of investors are based on possible gains and losses instead of final output of that investment. This notion arises because of cognitive errors that affect the analysis of these gains and losses. Every information regarding stock market is not conveniently available because buzzes move-on in the market, consequently, inaccessibility of relevant information and cognitive biases are the causes of the deviation from the expected result of investment decisions (Jaiyeoba \& Haron, 2016). Subsequently, lack of information and uncertain situation leads investors toward herd the actions of others and make decision on the bases of other's actions (Fernández et al., 2011). Herding appears in the stock market when many investors simultaneously imitate the actions of other investors due to lack of knowledge and restricted information in the markets (Kumar \& Goyal, 2016; Ngoc, 2014). Consequently, in the results of herding, investors copy to other investors and overlook their personal information and analysis.

In the presence of herding behaviour in stock market, trading volume and volatility of market are at highest levels. This behaviour leads investors towards over-speculation because investors copy the acts of others without proper information and analysis (Caparrelli, D'Arcangelis, \& Cassuto, 2004). In speculative environment, the prices of assets and volatility of market are significantly higher as compared to fundamental values of that asset. Therefore, behaviour of investors push the stock prices far away from fair value of stock because of price momentum and excess volatility and subsequently creates stock price bubbles (Chiang et al., 2015; Gębka \& Wohar, 2013; Nofsinger \& Sias, 1999). This behaviour not only create price momentum and excess volatility but it also proves to be harmful for whole stock market (Prieto \& Perote, 2017). It does not leads only to the formation of the bubble but it also leads to the bursting of bubble and subsequently drops the assets prices (Levine et al., 2014). Bursting of bubbles is an indication of financial instability that often creates stock market crash (Caparrelli et al., 2004; Parisi, Sornette, \& Helbing, 2013). Ultimately, instability of stock market could be destructive for the whole economy of a country (Husain \& Mahmood, 2001). According to Das (2011), some factors like and age of investors, education level, and knowledge about the financial system have significant influence on behaviour of investors. 
Literature shows that inexperience and younger have greater tendency to herd compare to older and experience investors. (Chevalier \& Ellison, 1999; Lin, 2011; Welch, 2000). Therefore, age has significant negative relationship with herding behaviour of stock market investors. However, some studies argued that age has positive relationship with herding behaviour (Kumar \& Goyal, 2016; Sultana \& Butterfield, 2010). Ironically, few other studies found that investors demonstrate herding behaviour regardless of the age (Ashiya \& Doi, 2001; Das, 2011; Zaidi \& Tauni, 2012). Lin (2011) and Hon-Snir, Kudryavtsev, and Cohen (2012) argued that female investors are more prone in herding because women are usually more risk averse, and less overconfident compared to the men (Barber \& Odean, 2001). While, some of the studies argued that male investors having greater tendency to herd compare to female (Bashir et al., 2013; Kumar \& Goyal, 2016). Talha, Ramanakumar, and Neelakantan (2015), found that individual investors' level of income affect the behaviour of investors. Hence, there is a conflict among studies; few studies demonstrate that age and income have a positive relation with herding, on the other hand, few studies argues that age and income negatively affect herding behaviour of investors. Hence, according to Baron and Kenny (1986), the situation is ideal to use a moderator, as there is a conflict among studies. The relationship of demographic variables (Age, Gender and Income), and herding behaviour can be moderate through the role of religiosity.

Religion can be a powerful factor in the development of human attitudes and behaviour (Essoo \& Dibb, 2004; Sham \& Yusof, 2015). Religion is associated with two key aspects namely religious affiliation and religiosity (Jamaludin, 2013). Religious affiliation indicates to the particular religious group to which an individual belongs and religiosity is defined as "the strength of people's faith in the existence and commandments of God, their relationship with divinity, their acting in accordance with religious principles and their observing practices concerning various aspects of life" (Alhouti et al., 2015). Religiosity also denote as religiousness or religious conviction, decision this term is used in a sociology to indicate the several aspects of religion in the behaviour and mind-set of its observers (Singhapakdi et al., 2013). People demonstrate their religiosity through religious activities, adherence to services, devotion to strategy and service to their religion. Religion is one of the most persuasive value systems that offer not only a code of conduct to billions of their followers around the world by which they live their lives, but also give a social identity (Ysseldyk, Matheson, \& Anisman, 2010).

Religiosity has impact on every decisions of life including investment decisions. Tahir and Brimble (2011) investigated the impact of Islamic religiosity and investment principles on the behaviour of Muslim investors and found that religion is one of those factors that have a significant affect on decision of asset allocation. Additionally, they claimed that Islam has a substantial influence on decision making of Muslim regarding investment. Though, the degree of influence of the Islamic investment principles on the investment decisions depends on the level of their religiosity. Islamic religiosity prohibits the herding behaviour of investors because it leads towards gambling and gharar in the equity market. In herding behaviour, investors act in equity market on the piece of unknown information that is a type of gambling according to Islam.

"Ibn 'Abbas said: Allah's Apostle said, "Do not go to meet the caravans on the way (for buying their goods without letting them know the market price); a town dweller should not sell the goods of a desert dweller on behalf of the latter." (The narrator) asked Ibn "Abbas, "What does he mean by not selling the goods of a desert dweller by a town dweller?" He said, "He should not become his broker." (Sahih al-Bukhari, Book 3, Volume 34, Hadith 367)"

Gambling is strictly forbidden in Quran, Allah says in surah 5 verses 9o:

"O you who have believed, indeed, intoxicants, gambling, [sacrificing on] stone alters [to 
other than Allah], and divining arrows are but defilement from the work of Satan, so avoid it that you may be successful”. (Al-Maidah 5:90)

In Islam gambling is forbidden, therefore any behavioural bias of investors that lead toward gambling is not permissible. Therefore, at the time of making investment decision in stock market, the Muslim investors must not indulge in herding behaviour because herding behaviour is root cause of gambling and this type of behaviour is forbidden in Islamic religiosity. Hence, Islamic religiosity could mitigate the herding behaviour of investors. Therefore, this study made one of the attempts to examine the direct and indirect effect of demographic factors through moderator (religiosity) on herding behaviour to reveal whether the religiosity mitigate the herding behaviour. The ultimate aim of this study is to highlight the role of the demographic factors on herding behaviour with moderating role of Islamic religiosity. The conceptual framework for this study is given below.

\section{Literature Review}

The research study focuses on the effect of demographic variables (Age, gender and income) on herding behaviour of individual investors and moderating effect of religiosity on the relationship of demographic variables and herding behaviour. According to the prior studies, it is observed that demographic variables affect herding behaviour (Kumar \& Goyal, 2016; Lin, 2011), but it have mixed results, therefore religiosity could moderates the relationship.

\subsection{Age and Herding Behaviour}

Age has been stated, in many research studies, to have a significant positive relationship with herding behaviour of investors (Geetha \& Ramesh, 2012; Korniotis \& Kumar, 2013; Kumar \& Goyal, 2016; Sultana \& Butterfield, 2010). Age affects the risk taking attitude, and age has positive relation with risk tolerance (Wang \& Hanna, 1997) while, risk taking attitude has negative relation with herding, therefore, age has negative relation with herding. Lin (2011), also highlighted that age had negative relationship with herding behaviour of investors, because older investors had lot of investment experience, so older investors used their private information while taking a financial decision. In young age investors do not have much experience and for the risk aversion purpose investors have more tendency to follow others investors like friends, peers, relatives and colleagues. Similarly, Kaur and Kaushik (2016) argued that age affect investment decision negatively due to conservative investment behaviour of investors. Semilirly, Dash (2010) decomented that individual investors choose investment opportunities according to their risk taking attitude. He concluded that age negatively affact risk taking attitude, younger investors exhibited more excitement on avalability of different types of investments in market. On the other hand, studies by Ashiya and Doi (2001) and Zaidi and Tauni (2012), claimed that there is no significant relationship between age and herding behaviour of the investors. However, Islam as a religion provide guidelines to its followers in the selections of financial and non-financial product in every age (Ahmed, 2010). There are controversial findings related to age and investment behaviour of invstors. Most of the studies indicated that risk taking attitude was increased with age (J. E. Grable, 2000). While, other researchers report that younger investors were more risk tolerant comared to older ones (Dash, 2010; J. Grable, Lytton, \& O'Neill, 2004). By sum up, age has a significant relationship with herding behaviour, as it is an essential element to shaping the risk tolerance attitude. But religiosity could moderate the relationship of age and herding behaviour. Accordingly, it is hypothesized that: $\mathbf{H}_{\mathbf{1}}$ : Age has significant relationship with herding behaviour of investors.

$\mathbf{H}_{2}$ : Islamic religiosity moderates the relationship between age and herding behaviour of investors. 


\subsection{Gender and Herding Behaviour}

Gender has been a largely studied demographic factor, along with risk taking attitude and herding behaviour. Previous literature on the relationship of gender with herding among investors shows mixed results. Chavali and Raj (2016), investigated that gender influenced risk aversion and women investors were more risk averse compared to men investors. Men investors take more risky investment decision and invest in risky shares because women feel less confident and have risk averse attitude in financial decision making (Heath \& Tversky, 1991). Additionally, Hon-Snir et al. (2012) and Lin (2011) also found a negative relationship between men and herding behaviour, While, Kumar and Goyal (2016) and Bashir et al. (2013) found positive significant relationship between male investors and herding behaviour. Moreover, Khan, Tan, and Chong (2016) investigated gender differences in selection of investments of institutional investors and financial professionals in Malaysia. They found significant gender differences in the selection of investment alternatives and firm preferences, which is likely to describe the gender gap in investment behaviour. They found that female individual investors give more weightage to the stock price, sales volume of the firm, firm's liquidity, dividend pay-out ratio, and age of the firm as compared to the male investors. On the other hand, Loibl and Hira (2007) found that women are usually more risk averse, and less overconfident compared to the men (Barber \& Odean, 2001). Finally, from above discussion, it is concluded that gender can affect the herding behaviour of investor. However, the role of religiosity cannot be neglected, as it is important in shaping the behaviour of individuals. Accordingly, it is hypothesized that:

$\mathbf{H}_{3}$ : Gender has significant relationship with herding behaviour of investors.

$\mathbf{H}_{4}$ : Islamic religiosity moderates the relationship between gender and herding behaviour of investors.

\subsection{Income and Herding Behaviour}

Income level of individuals determine their risk taking attitude and trading behaviours (Chandra, Sanningammanavara, \& Nandini, 2017). Income has a significant role in determining the investment behaviour of investors (Kaleem, Wajid, \& Hussain, 2009).

Mohanta and Debasish (2011) and Harikanth and Pragathi (2012) found positive relationship between income and risk taking behaviour. Risk taking behaviour negatively affects herding behaviour (Lütje, 2009). Therefore, level of income negatively affects herding behaviour. Talha et al. (2015), found significant negative relationship between level of income and herding behaviour. While, Pak and Mahmood (2015) found positive relationship between income and risk taking behaviour. Similarly, Pak and Mahmood (2015) found that subjects with higher incomes exhibited lower risk aversion as compare to subjects with lower incomes. Additionally, Geen (2013) found that women having high income were more risk taker as compare to men. This difference was attributed to women's greater sensitivity to income than men. Conversely, Nguyen and Schuessler (2012) conducted a study on German investors to find out the impact of demographic variables on the behaviour of investors. They conducted survey on thirteen hundred individual German investors and found that education, experience and income of the investors had negative impact on herding behaviour of German investors. However, Lin (2011), found no significant relationship between income and herding behaviour. Hence, from above literature, it is discovered that income has association with herding behaviour but it has mixed results so, this association can be moderated by religiosity. Accordingly, it is hypothesized that:

$\mathbf{H}_{5}$ : Income has significant relationship with herding behaviour of investors.

$\mathbf{H}_{6}$ : Islamic religiosity moderates the relationship between Income and herding behaviour of investors. 


\subsection{Research Model}

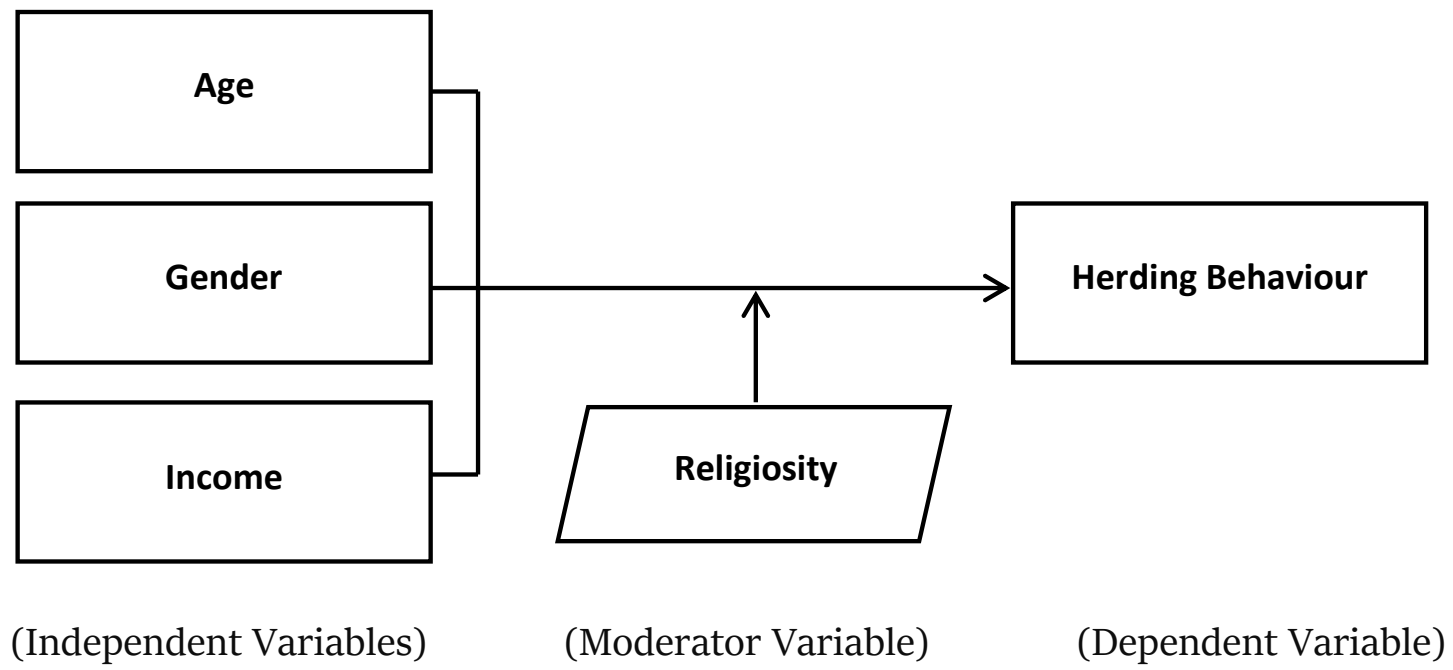

Fig. 1: Theoretical framework

\section{Methodology}

Quantitative research approach employed in contemporary study employed and questionnaire was used to collect the data from individual investors participating in Pakistan stock exchange for the testing of hypothesis. This method is a suitable to collect data within a short period and in a limited cost (Sekaran \& Bougie, 2003). All construct were measured using five-point Likert scale ranged from 1 (strongly disagree) to 5 (strongly agree). All scales were adapted from previous studies. The items for measuring religiosity adapted from the research of Shukor and Jamal (2013). As for herding behaviour scale of Prosad, Kapoor, and Sengupta (2015) were adapted. Convenience sampling used for the collection of data. About 400 survey questioners were distributed but only 166 questionnaires were returned back (41\% response rate) and 11 questionnaires were excluded due to incomplete and 155 questionnaires were used to analyse the data (38.75\% actual response rate).

\section{Data Analysis and Results}

Smart-Partial Least Square (SEM-PLS) version 3.2.7 was employed to estimate the research model of contemporary study.

\subsection{Measurement Model Assessment}

\subsubsection{Confirmatory Factor Analysis}

Table 1. Convergent validity, Cronbach's alpha, Composite Reliability, AVE

\begin{tabular}{|l|l|l|l|l|l|}
\hline Construct & Indicators & Loadings & $\begin{array}{l}\text { Cronbach's } \\
\text { alpha }\end{array}$ & $\begin{array}{l}\text { Composite } \\
\text { Reliability } \\
\text { (CR) }\end{array}$ & AVE \\
\hline Herding & HB2 & 0.743 & 0.835 & 0.880 & 0.551 \\
& HB3 & 0.839 & & & \\
& HB4 & 0.638 & & & \\
& HB5 & 0.780 & & & \\
& HB6 & 0.744 & & & \\
& HB7 & 0.694 & & & \\
\hline
\end{tabular}




\begin{tabular}{|l|l|l|l|l|l|}
\hline Religiosity (R) & R1 & 0.602 & 0.886 & 0.914 & 0.610 \\
& R2 & 0.873 & & & \\
& R3 & 0.835 & & & \\
& R5 & 0.849 & & & \\
& R6 & 0.878 & & & \\
& R7 & 0.751 & & & \\
& R8 & 0.708 & & & \\
\hline
\end{tabular}

Table 1 represents the findings of convergent validity that is inspected by the value factor loading, CR values of every variable, and AVE values for the scale of each construct (Hair et al., 2010). Findings directed that values of factor loadings of every item is above the threshold that is o.6 (Chin, Gopal, \& Salisbury, 1997). CR values were higher then suggested level that is 0.7 (Hair et al., 2010). Moreover, the values of AVE are also higher then the recommended vale of 0.50 (Hair et al. 2010).

\subsubsection{Discriminant Validity}

Table 2. Heterotrait - Monotrait Ratio

\begin{tabular}{|l|l|l|l|l|l|}
\hline & Age & Gender & HB & Income & R \\
\hline Age & & & & & \\
\hline Gender & 0.025 & & & & \\
\hline HB & 0.131 & 0.050 & & & \\
\hline Income & 0.251 & 0.034 & 0.051 & & \\
\hline R & 0.085 & 0.044 & 0.472 & 0.046 & \\
\hline
\end{tabular}

HTMT ratio represents discriminant validity if these are less than 0.85 (Kline, 2011). Values of all ratios are according the threshold value that shows discriminant validity of model.

\subsection{Structure Equation Modeling}

The structural model analysis investigate the relations between independent variables and dependent variable of model (Sang, Lee, \& Lee, 2010).

\subsubsection{Path Modeling}

Table 3. Direct Effects

\begin{tabular}{|l|l|l|l|l|l|l|}
\hline Hypothesis & Relationship & Beta & S.E. & t-Value & P-Value & Decision \\
\hline $\mathbf{H}_{\mathbf{1}}$ & Age -> HB & -0.126 & 0.064 & 1.980 & 0.048 & Supported \\
\hline $\mathbf{H}_{\mathbf{3}}$ & Gender -> HB & -0.071 & 0.109 & 0.653 & 0.514 & Not Supported \\
\hline $\mathbf{H}_{\mathbf{5}}$ & Income -> HB & -0.164 & 0.075 & 2.186 & 0.004 & Supported \\
\hline
\end{tabular}

Table 3 illustrates results of direct effects. Findings shows that $\mathrm{H}_{1}$ with $(\beta=-0.126, t=1.980)$ and $\mathrm{H}_{5}$ with $(\beta=-0.164, \mathrm{t}=2.186)$ accepted. It shows that age and income had negative relationship with herding behaviour of Pakistani investors. The results of this study are in-line with results of (Kumar \& Goyal, 2016). Results demonstrate that increase in age and income of investors discourages herding behaviour among individual investors of Pakistan stock exchange. While, $\mathrm{H}_{3}$ Was not accepted. 
Table 4. Moderating effect results

\begin{tabular}{|l|l|l|l|l|l|l|}
\hline Hypothesis & Relationship & Beta & S.E. & t-Value & P-Value & Decision \\
\hline $\mathbf{H}_{\mathbf{2}}$ & Age $^{\star} \mathrm{R}->\mathrm{HB}$ & -0.156 & 0.063 & 2.476 & 0.00 & Moderate \\
\hline $\mathbf{H}_{\mathbf{4}}$ & Gender $\mathrm{R}->\mathrm{HB}$ & -0.037 & -0.029 & 1.275 & 0.455 & Not Moderate \\
\hline $\mathbf{H}_{\mathbf{6}}$ & Income ${ }^{\star} \mathrm{R}->\mathrm{HB}$ & -0.189 & 0.067 & 2.820 & 0.002 & Moderate \\
\hline
\end{tabular}

Moderating effect results presented in Table 4. These findings directed that Islamic religiosity moderate the relationship of Age and income with herding behaviour while $\mathrm{H}_{4}$ was not supported. Moreover, findings illustrated that Islamic religiosity enhance negative relationship of age and income with herding behaviour.

\section{Discussion and Conclusion}

Retail investors of Pakistan stock exchange (PSX) indulge in irrational herding behaviour due to age and income factors because these factors affect risk taking attitude. This study highlighted the role of demographic factors and Islamic religiosity on herding behaviour of stock market investors. Findings determined that younger investors more prone to herding due to less experience. Moreover, investors with less income demonstrate risk adverse attitude and follow to others at the time of making investment decision making. The critical observation of relevant literatures concluded that there is a significant conceptual relationship between Islamic religiosity and behaviour of Muslim in every matter of life. This research study is contributing to the body of knowledge by developing a unique framework for mitigation of investors' herding behaviour in stock markets. The results also indicated that Islamic religiosity mitigate herding behaviour of individual investors in the context of Pakistan stock market.

The results of this study are significant for the policy makers of PSX. Results suggested that Islamic religiosity is one of the most important factors for that affect the behaviour of individual Muslim investors. However, the generalizability of current study's results is quite tough because this research study used convenience sampling, in future research, researcher can use any other suitable sampling method for generalizing results. Moreover, future research can use variable other than demographic factors, such as attitudinal factors.

\section{References}

Ahmed, A. (2010). Global financial crisis: an Islamic finance perspective. International Journal of Islamic and Middle Eastern Finance and Management, 3(4), 306-320.

Alhouti, S., Gillespie, E. A., Chang, W., \& Davis, L. (2015). The thin line between love and hate of attention: The customer shopping experience. Journal of Marketing Theory and Practice, 23(4), 415-433.

Ashiya, M., \& Doi, T. (2001). Herd behavior of Japanese economists. Journal of Economic Behavior \& Organization, 46(3), 343-346.

Barber, B. M., \& Odean, T. (2001). Boys will be boys: Gender, overconfidence, and common stock investment. The quarterly journal of economics, 116(1), 261-292.

Bashir, T., Ahmed, H. R., Jahangir, S., Zaigam, S., Saeed, H., \& Shafi, S. (2013). Investment preferences and risk level: Behaviour of salaried individuals. IOSR Journal of Business and management, 10(1), 68-78.

Bosner, K., \& Lakehal-Ayat, M. (2008). A comparison of risk tolerance and risk capacity among college finance students. Academy of Accounting and Financial Studies Journal, 12(1), 67.

Caparrelli, F., D'Arcangelis, A. M., \& Cassuto, A. (2004). Herding in the Italian stock market: a case of 
behavioral finance. The Journal of Behavioral Finance, 5(4), 222-230.

Chandra, A., Sanningammanavara, K., \& Nandini, A. S. (2017). Does individual heterogeneity shape retail investor behaviour? International Journal of Social Economics, 44(5), 578-593.

Chavali, K., \& Raj, P. (2016). Impact of Demographic Variables and Risk Tolerance on Investment Decisions: An Empirical Analysis.

Chevalier, J., \& Ellison, G. (1999). Career concerns of mutual fund managers. The Quarterly Journal of Economics, 114(2), 389-432.

Chiang, T. C., Li, J., Tan, L., \& Nelling, E. (2015). Dynamic herding behavior in Pacific-Basin markets: Evidence and implications.

Chin, W. W., Gopal, A., \& Salisbury, W. D. (1997). Advancing the theory of adaptive structuration: The development of a scale to measure faithfulness of appropriation. Information systems research, $8(4), 342-367$.

Das, S. K. (2011). An empirical analysis on preferred investment avenues among rural and semi-urban households. Journal of Frontline Research in Arts and Science, 1, 26-36.

Dash, M. K. (2010). Factors influencing investment decision of generations in India: An econometric study. International Journal of Business Management Economic Res, 1(1), 15-26.

Essoo, N., \& Dibb, S. (2004). Religious influences on shopping behaviour: An exploratory study. Journal of Marketing Management, 20(7-8), 683-712.

Fernández, B., Garcia-Merino, T., Mayoral, R., Santos, V., \& Vallelado, E. (2011). Herding, information uncertainty and investors' cognitive profile. Qualitative Research in Financial Markets, 3(1), 733.

Gębka, B., \& Wohar, M. E. (2013). International herding: Does it differ across sectors? Journal of International Financial Markets, Institutions and Money, 23, 55-84.

Geen, A. (2013). Risk in the background: how men and women respond: Working Paper, Ramous University Rotterdam, Netherlands.

Geetha, N., \& Ramesh, M. (2012). A study on relevance of demographic factors in investment decisions. Perspectives of Innovations, Economics and Business, 10(1), 14-28.

Grable, J., Lytton, R., \& O'Neill, B. (2004). Projection bias and financial risk tolerance. The Journal of Behavioral Finance, 5(3), 142-147.

Grable, J. E. (2000). Financial risk tolerance and additional factors that affect risk taking in everyday money matters. Journal of Business and Psychology, 14(4), 625-630.

Hair, Black, W. C., Babin, B. J., Anderson, R. E., \& Tatham, R. (2010). Multivariate data analysis (Vol. 7): Pearson.

Harikanth, D., \& Pragathi, B. (2012). Role of Behavioural Finance in Investment Decision Making-A Study on Select Districts of Andhra Pradesh, India. International Journal in Multidisciplinary and Academic Research (SSIJMAR), 1(4), 1-15.

Heath, C., \& Tversky, A. (1991). Preference and belief: Ambiguity and competence in choice under uncertainty. Journal of risk and uncertainty, 4(1), 5-28.

Hoffmann, A. O., Post, T., \& Pennings, J. M. (2013). Individual investor perceptions and behavior during the financial crisis. Journal of Banking \& Finance, 37(1), 6o-74.

Hon-Snir, S., Kudryavtsev, A., \& Cohen, G. (2012). Stock market investors: who is more rational, and who relies on intuition? International Journal of Economics and Finance, 4(5), 56.

Husain, F., \& Mahmood, T. (2001). The stock market and the economy in Pakistan. The Pakistan Development Review, 107-114.

Jaiyeoba, H. B., \& Haron, R. (2016). A qualitative inquiry into the investment decision behaviour of the Malaysian stock market investors. Qualitative Research in Financial Markets, 8(3), 246-267.

Jamaludin, N. (2013). Religion and individual investment choice decision: the case of Malaysia. International Journal of Business and Social Science, 4(1). 
Kaleem, A., Wajid, R. A., \& Hussain, H. S. (2009). Factors Affecting Financial Advisor's Perception in Portfolio Management: With Reference to Pakistan. Paper presented at the 2009 Oxford Business and Economics Conference Program, June.

Kaur, I., \& Kaushik, K. (2016). Determinants of investment behaviour of investors towards mutual funds. Journal of Indian Business Research, 8(1), 19-42.

Khan, M. T. I., Tan, S.-H., \& Chong, L.-L. (2016). Gender differences in preferences for firm characteristics across different groups of investors. Qualitative Research in Financial Markets, $8(1), 2-15$.

Kline, R. B. (2011). Convergence of structural equation modeling and multilevel modeling: na.

Korniotis, G. M., \& Kumar, A. (2013). Do portfolio distortions reflect superior information or psychological biases? Journal of Financial and Quantitative Analysis, 48(1), 1-45.

Kumar, S., \& Goyal, N. (2016). Evidence on rationality and behavioural biases in investment decision making. Qualitative Research in Financial Markets, 8(4), 270-287.

Levine, S. S., Apfelbaum, E. P., Bernard, M., Bartelt, V. L., Zajac, E. J., \& Stark, D. (2014). Ethnic diversity deflates price bubbles. Proceedings of the National Academy of Sciences, 111(52), $18524-18529$.

Lin, H.-W. (2011). Elucidating rational investment decisions and behavioral biases: Evidence from the Taiwanese stock market. African Journal of Business Management, 5(5), 1630.

Loibl, C., \& Hira, T. K. (2007). New Insights into Advising Female Clients on Investment Decisions. Journal of Financial Planning, 20(3).

Lütje, T. (2009). To be good or to be better: asset managers' attitudes towards herding. Applied Financial Economics, 19(10), 825-839.

Mohanta, G., \& Debasish, S. S. (2011). A study on investment preferences among urban investors in Orissa. Prerna Journal of Management Thought and Practice, ISSN, 974, 1-9.

Nga, J. K., \& Ken Yien, L. (2013). The influence of personality trait and demographics on financial decision making among Generation Y. Young Consumers, 14(3), 230-243.

Ngoc, L. T. B. (2014). Behavior pattern of individual investors in stock market. International Journal of Business and Management, 9(1), 1.

Nguyen, T., \& Schuessler, A. (2012). Investment decisions and socio-demographic characteristicsempirical evidence from Germany. International Journal of Economics and Finance, 4(9), 1.

Nofsinger, J. R., \& Sias, R. W. (1999). Herding and feedback trading by institutional and individual investors. The Journal of finance, 54(6), 2263-2295.

Pak, O., \& Mahmood, M. (2015). Impact of personality on risk tolerance and investment decisions: A study on potential investors of Kazakhstan. International Journal of Commerce and Management, 25(4), 370-384.

Parisi, D. R., Sornette, D., \& Helbing, D. (2013). Financial price dynamics and pedestrian counterflows: A comparison of statistical stylized facts. Physical Review E, 87(1), 012804.

Prieto, P. M., \& Perote, J. (2017). Agents' Behavior in Market Bubbles: Herding and Information Effects. Economics, 5(1), 44-51.

Prosad, J. M., Kapoor, S., \& Sengupta, J. (2015). Behavioral biases of Indian investors: a survey of DelhiNCR region. Qualitative Research in Financial Markets, 7(3), 230-263.

Sabir, S. A., Mohammad, H. B., \& Shahar, H. B. K. (2018). The Effect of Illusion of Control and Self Attribution on Herding Behaviour with A Moderating Role of Information Availability: A Case of Retail investors of Pakistan Stock Exchange. Opción, 34(86), 16.

Sang, S., Lee, J.-D., \& Lee, J. (2010). E-government adoption in Cambodia: a partial least squares approach. Transforming Government: People, Process and Policy, 4(2), 138-157.

Sekaran, U., \& Bougie, R. (2003). Research methods for business: A skill building approach. Singapore: Willey. 
Sham, F. M., \& Yusof, S. (2015). Religiosity of Muslim adolescents from single parent families living in government-subsidised settlement. Global Journal Al-Thaqafah, 5(2), 31-42.

Shukor, S. A., \& Jamal, A. (2013). Developing scales for measuring religiosity in the context of consumer research. Middle-East Journal of Scientific Research, 13(1), 69-74.

Singhapakdi, A., Vitell, S. J., Lee, D.-J., Nisius, A. M., \& Grace, B. Y. (2013). The influence of love of money and religiosity on ethical decision-making in marketing. Journal of Business Ethics, 114(1), 183-191.

Spyrou, S. (2013). Herding in financial markets: a review of the literature. Review of Behavioral Finance, 5(2), 175-194.

Sultana, R., \& Butterfield, D. A. (2010). Role of oxidative stress in the progression of Alzheimer's disease. Journal of Alzheimer's Disease, 19(1), 341-353.

Tahir, I., \& Brimble, M. (2011). Islamic investment behaviour. International Journal of Islamic and Middle Eastern Finance and Management, 4(2), 116-130.

Talha, M., Ramanakumar, K., \& Neelakantan, P. (2015). Investor Psychology and its Influence on Investment Decisions.

Tversky, A., \& Kahneman, D. (1973). Availability: A heuristic for judging frequency and probability. Cognitive psychology, 5(2), 207-232.

Wang, H., \& Hanna, S. D. (1997). Does risk tolerance decrease with age?

Welch, I. (2000). Herding among security analysts. Journal of Financial Economics, 58(3), 369-396.

Ysseldyk, R., Matheson, K., \& Anisman, H. (2010). Religiosity as identity: Toward an understanding of religion from a social identity perspective. Personality and Social Psychology Review, 14(1), 6071.

Zaidi, F. B., \& Tauni, M. Z. (2012). Influence of investor's personality traits and demographics on overconfidence bias. Institute of Interdisciplinary Business Research, 4(6), 730-746. 